Jurnal Teknik Hidro

Vol. 11 No. 1, Februari 2018

\title{
PERBANDINGAN HIDROGRAF SATUAN AMATAN DAN HIDROGRAF SATUAN SINTESIS \\ (DAS MAROS SUB DAS MAROS TOMPUBULU)
}

\author{
M. Agusalim ${ }^{(1}$ Abd. Rakhim Nanda ${ }^{(2}$ Soemitro Emin Praja ${ }^{(3}$ Erwin Syah $^{(4}$ \\ ${ }^{1)}$ Universitas Muhammadiyah Makassar, Indonesia \\ Email : m.agusalim2@gmail.com \\ ${ }^{2}$ Universitas Muhammadiyah Makassar, Indonesia \\ Email :rahim_nanda@yahoo.co.id \\ ${ }^{3}$ Universitas Muhammadiyah Makassar, Indonesia \\ Email : soemitroeminpraja@gmail.com \\ ${ }^{4}$ Universitas Muhammadiyah Makassar, Indonesia \\ Email : erwinsyah@gmail.com
}

\begin{abstract}
Abstrak
Tujuan penelitian untuk mengetahui persentase perbedaan hasil perhitungan antara hidrograf satuan amatan (Metode Collins) dengan metode hidrograf satuan sintesis (Metode Snyder) dan (Metode Nakayasu), untuk mengetahui parameter-parameter yang digunakan dalam kedua metode tersebut mengakibatkan perbedaan debit puncak (Qp), waktu mencapai puncak (Tp) dan waktu dasar (Tb) pada kedua metode tersebut. Dari hasil penelitian ini, maka kami dapat menarik beberapa kesimpulan terkait Penerapan Metode HS Collins dan HSS Snyder Pada DAS Maros sub DAS Maros-Tompobulu yaitu, kedua metode yang digunakan dalam tugas akhir ini memiliki parameter yang berbeda dalam pengaruh terhadap perubahan waktu mencapai puncak dan debit puncak. Pada metode HS Collins parameter Lc menjadi sangat berpengaruh untuk perubahan waktu mencapai puncak. Dan pada metode HS Snyder parameter $\alpha$ dan tg yang menjadi sangat berpengaruh untuk perubahan waktu mencapai puncak.
\end{abstract}

Kata Kunci : Hidrograf, Desain Banjir, Observasi, Sintesis

\begin{abstract}
The objective of the research is to know the percentage of difference of calculation result between hydrograph unit observation (Method of Collins) with synthesis unit synthesis method (Snyder Method) and (Nakayasu Method), To know the parameters used in both methods resulted in difference of peak discharge ( $Q p)$, peak time (Tp) and base time (Tb) in both methods. And the results of the observase, we can draw some conclusions related to the Implementation of HS Collins and HSS Snyder Methods In Maros MarosTompobulu Maros Watershed, that is, the two methods used in this final project have different parameters in influence on the change Time reaches peak and peak discharge. In the HS Collins method the Lc parameter becomes very influential for the peak time change. And on HS Snyder method parameters $\alpha$ and tg which become very influential for time change reaches peak.
\end{abstract}

Keywords: Hydrograph, Flood design, Observation, Synthesis

ISSN : 19799764 


\section{PENDAHULUAN}

Banjir rancangan (design flood) adalah salah satu besaran rancangan untuk suatu rencana pembuatan bangunan air atau bangunan yang keberadaannya (fungsi operasi dan stabilitas) dipengaruhi oleh karakteristik aliran banjir. Banjir rancangan dapat diperoleh melalui kegiatan analisis hidrologi yang secara umum hasilnya dapat berupa debit banjir maksimum, volume banjir, ataupun atau hidrograf banjir. Dalam hal ini, banjir rancangan merupakan debit banjir yang ditetapkan sebagai dasar penentuan kapasitas untukmendimensi bangunan-bangunan air (termasuk bangunan di sungai), sedemikian hingga kerusakan yang dapat ditimbulkan baik langsung maupun tidak langsung oleh banjir tidak boleh terjadi selama besaran banjir tidak terlampaui (Sri Harto, 1993).

\section{Hidrograf}

1) Bambang Triadmojo (2008) membagi hidrograf menjadi tiga komponen, diantaranya yaitu sisi naik (rising limb). Sisi naik (rising limb) bagian antara waktu nol (0) dan waktu puncak. Sisi turun (recession limb) adalah bagian hidograf yang menurun antara waktu puncak dan waktu dasar. Waktu dasar (time base) adalah waktu yang diukur dari waktu nol sampai dimana sisi turun berakhir.Selain itu komponen hirograf dapat ditandai dengan tiga komponen sifat pokoknya, yaitu naik (time of rise), debit puncak (peak discharger) dan waktu dasar (base time).

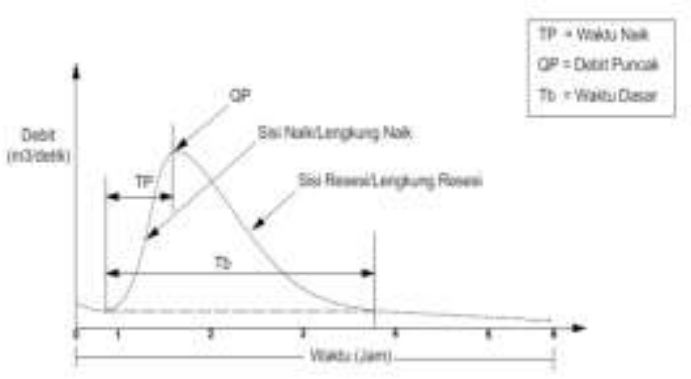

Gambar 1. Komponen Hidrograf

\section{Hidrograf Satuan}

Sherman (1932), mengenalkan konsep hidrograf satuan,yang banyak digunakan untuk melakukan transformasi dari hujan menjadi debit aliran. hidrograf satuan didefenisikan sebagi hidrograf limpasan (tanpa aliran dasar) yang tercatat di ujung hili DAS ang ditimbulkan oleh hujan efektif sebesar $1 \mathrm{~mm}$ yang terjadi secara merata di permukaan DAS dengan intensitas tetap dalam suatu durasi tertentu. 
1) Hidrograf banjir berpuncak tunggal, hal ini dimaksud untuk mempermudah analisis.

2) Hujan penyebab banjir terjadi merata di seluruh DAS, hal ini dipilih untuk memenuhi kriteria teori hirograf satuan.

3) Dipilih kasus banjir dengan debit puncak yang relatif cukup besar.

Berdasarkan kriteria tersebut maka akan terdapat beberapa kasus banjir. Untuk masing -masing kasus banjir diturunkan hidrograf satuannya. Hidrograf satuan yang dianggap mewakli DAS yang ditinjau adalah hidrograf satan rerata yang diperoleh dari kasus banjir tersebut.

\section{Penurunan Hidrograf Satuan}

Bambang Triadmojo (2008), berpendapat untuk menurunkan hidrograf satuan diperlukan data hujan dan debit aliran berkaitan. Prosedur penurunan hidrograf satuan adalah sebagai berikut ini :

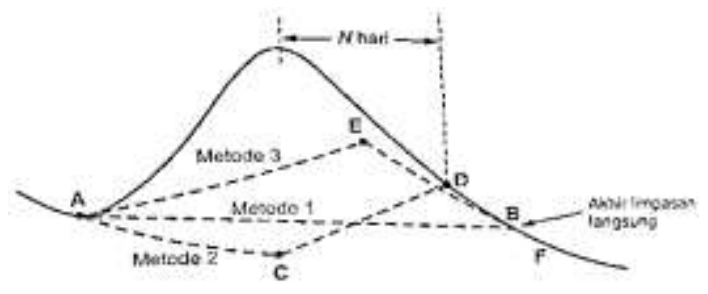

Gambar 2: Pemisahan Aliran Dasar
1) Memisahan aliran dasar dari hidrograf limpasan langsung, ada beberapa metode dalam pemisahan aliran dasar dianataranya:

a) Cara paling sederhana adalah dengan menarik garis lurus dari titik dari titik dimana aliran langsung mulai terjadi (A) samapai akhir dari aliran langsung (B). Apabila titik tidak diketahui, maka garis horizontal dari titik (A).

b) Cara kedua adalah membuat garis yang merupakan perpanjangan kelanjutan dari aliran dasar sampai titik (C) yang berada dibawa puncak hidrograf. Dari titik (C) kemudian ditarik garis lurus menuju titik (D) yang berada pada sisi turun yang berjarak $(\mathrm{N})$ hari sesudah puncak. Nilai (N) dihitung dengan rumus berikut:

$N=0.8 A^{0,2}$

Dengan :

$\mathrm{N}$ : waktu (hari)

A: Luas DAS $\left(\mathrm{km}^{2}\right)$

c) Cara ketiga adalah menarik kurva resesi ke belakang yang berawal dari titik aliran langsung (B) sampai ketitik (E) dibawa titik balik. 
Hubungkan titik (A) dengan garis lurus atau kurva sembarang.

Perbedaan nilai aliran dasar karena penggunaan beberapa cara tersebut relatifkecil dibanding dengan volume hidrograf limpasan langsung.

1) Dalam penurunan hidrograf satuan yaitu, menghitung luasan dibawah hidrograf limpasan langsung yang merupakan volume aliran permukaan. Volume aliran tersebut dikonversi menjadi kedalaman aliran diseluruh DAS.

2) Ordinat dari hidrograf limpasan langsung dibagi dengan kedalaman aliran, yang menghasilkan hidrograf satuan dengan durasi sama dengan durasi hujan.

3) Menetapan hujan efektif untuk memperoleh hidrograf dilakukan denganmenggunakan indeks-infiltrasi. Perkiraan dilakukan dengan mempertimbangkan pengaruh parameter DAS yang secara hidrologidapat diketahui pengaruhnya terhadap indeks-infiltrasi. Persamaanpendekatannya sebagai berikut :

$\phi=10,4003.3,85910^{-6} A^{2}+1,6985.10^{-13}(\mathrm{~A}$ $/ \mathrm{SN})^{4}$
Untuk memperkirakan aliran dasar dipergunakan persamaan pendekatan

berikut ini :

$Q B=0,4751 A^{-0.1491} D^{0,9430}\left(m^{3} / \mathrm{dtc}\right) . .(3)$

Sedangkan dalam menetapkan hujan rata-rata DAS, perlu mengikuti cara-cara yangada. Tetapi bila dalam praktek analisis tersebut sulit, maka disarankan

menggunakan cara yang mengalikan hujan titik dengan

faktor reduksi hujan, sebesar :

$B=1,5518$

$A^{-0,1491} N^{-0,2725} S I M^{0,0259} S^{-0,0733}$

Berdasarkan persamaan di atas maka dapat dihitung besar debit banjir setiap jam dengan persamaan :

$Q p=(Q t * R e)+Q B\left(m^{3} / d t c\right)$

Dimana :

$\mathrm{Qp}=$ debit banjir setiap jam (m3/dtk)

$\mathrm{Qt}=$ debit satuan tiap jam (m3/dtk)

$\mathrm{Re}=$ curah hujan efektif ( $\mathrm{mm} / \mathrm{jam})$

$\mathrm{QB}=$ aliran dasar (m3/dtk)

Hidrograf Satuan Pengamatan Metode Collins 
Hidrograf satuan yang dihitung dari suatu kasus banjir belum merupakan hidrograf yang mewakili DAS yang bersangkutan. Oleh sebab itu diperlukan hidrograf satuan yang diturunkan dari sebuah kasus banjir, kemudian diratarata. Namun tidak ada petunjuk tentang berapa jumlah kasus banjir yang diperlukan untuk memperoleh hidrograf satuan ini.

Adapun tahapan penentuan hidrograf satuan dengan metode Collins dalam analisis banjir rancangan pada DAS Maros Sub Das Maros-Tompobulu di ilustrasikan dalam gambar 2 dan disertai penjelasan sebagai berikut:

1) Memilih data hujan jam-jaman otomatis dan hidrograf aliran terukur di DAS Maros

2) Memisahkan aliran dasar dan hidrograf limpasan langsung (HLL) dengan metode strigh line

3) Menetapkan nilai hujan efektif dengan metode indeks infiltrasi ( $\phi$ indeks )

4) Menetapkan sebuah hidrograf satuan perkiraan awal dengan menetapkan ordinat-ordinatnya dengan besaran tertentu (UH-1).
5) Menentukan hidrograf limpasan langsung akibat hujan efektif jamjaman kecuali untuk hujan terbesar.

6) Jumlahkan semua hidrograf limpasan langsung (HLL) ini dan hasilnya dikurangkan dengan hidrograf langsung terukur. Selisi hidrograf limpasan langsung yang didapatkan dibagi dengan hujan efektif jam-jaman yang maksimum. Hasilnya adalah hidrograf satuan baru (UH-2).

7) Hitung rerata UH-1 dan UH-2 sebagai UH-3 dan amati apakah cukup dekat dengan UH-1.

8) Apabila masih belum cukup dekat, ulangi langkah (4) sampai dengan langkah (7) dengan mengambil UH3 sebagai hidrograf satuan perkiraan awal yang baru. Prosedur ini diulangi sampai didapat hasil UH-3 yang cukup dekat dengan UH-1.

Berdasarkan hasil perhitungan hidrograf satuan pengamatan, kemudian diukur besaran Qp, Tp, dan Tb, kemudian dirata-ratakan. Pada hujan kompleks (bukan hujan tunggal), penurunan sebaiknya di-kerjakan dengan metode Collins untuk menghindari kesalahan beruntun (Sri Harto, 1993). 
Hidrograf satuan sintesis (HSS) Snyder pertama kali dikembangkan oleh Snyder (1938) di Amerika Serikat. Snyder mengembangkan rumus empiris dengan koefesien-koefesien

yang

menghubungkan unsur unusur hidrograf satuan dengan karesteristik daerah pengaliran. Pendekatan asli dikemukakan oleh Snyder memelihi empat paramater yaitu waktu keterlambatan, aliran puncak, waktu dasar,dan durasi standar dari hujan efektif untuk hidrograf satuan dikaitkan dengan geometri fisik dari DAS dengan hubungan berikut ini (Gupta, 1989).

Snyder membuat rumusan sebagai berikut :

$t_{p}=C_{t}\left(L L_{c}\right)^{n=0,3}$

$Q_{p}=\frac{C_{p} A}{T_{p}}$

$T=3+\frac{t_{p} A}{8}$.

$t_{D}=\frac{t_{p}}{5,5}$

Apabila durasi hujan efektif tr,tidak sama dengan durasi standar $t_{D}$,maka :

$t_{p R}=t_{p}+0,25\left(t_{r}-t_{D}\right)$

$Q_{p R} Q_{p} \frac{T_{p}}{T_{p R}}$
Dimana

$t_{p}$ : waktu dari titik berat hujan efektif ke puncak hidrograf satuan

$C_{t}$ : Koefesien yang tergantung pada karesteristik DAS, yang bervariasi antara1,4 smapai 1,7

L : Panjang sungai terhadap titik kontrol yang ditinjau $(\mathrm{km})$

$Q_{p}$ : Debit puncak durasi untuk $t_{D}$

$L_{C}$ :Panjang DAS utama dari titik berat / kontrol hujan bert efekti ke puncak hidrograf

$C_{P}$ : Koefesien yang tergantung pada karesteristik DAS,yang bervariasi antara 0,15 sampai 0,19

$t_{D}$ : Durasi standar dari hujan efektif ( jam )

$t_{p R}$ : Waktu dari titik berat durasi hujan efektif $t_{r}$ kepuncak hidrograf satuan (jam)

$t_{r}$ :Durasi Hujan Efektif ( jam )

$Q_{p R}$ : Debit Puncak untuk durasi $t_{r}$

\section{Hidrograf Satuan Sintesis}

Soemarto (1987), berpendapat dalam teori klasik tentang hidrograf satuan sintesis merupakan penerapan dari sistem linear dalam bidang hidrologi.

Keempat dalil tersebut adalah sebagai berikut :

1) Prinsip merata adalah hidrograf satuan ditimbulakan oleh satuan hujan lebih yang terjadi merata di seluruh DAS, selama waktu yang ditetapkan.

2) Prinsip waktu dasar konstan dalam suatu DAS adalah hidrograf satuan 


\section{Jurnal Teknik Hidro}

\section{Vol. 11 No. 1, Februari 2018}

yang di hasilkan oleh hujan-hujan efektif dalam waktu yang sama akan mempunyai waktu dasar,tanpa melihat insensitas hujan.

3) Prinsip linearitas adalah besaran limpasan langsung pada suatu DAS berbanding lurus terhadap tebal hujan efektif, yang berlaku bagi semua hujan dengan waktu yang sama.

4) Prinsip super posisi adalah total hidrograf limpasan langsung yang disebabkan oleh beberapa kajian hujan yang terpisah merupakan penjumlahan dari tiap tiap hidrograf satuan.

\section{Metode Satuan Sintesis Snyder}

Sebagai subject study pendukung penelitian, maka salah satu metode yang akan digunakan sebagai pembanding adalah hidrograf satuan sintesis adalah metode satuan sintesis snyder.

Snyder membuat rumusan sebagai berikut :

$t_{p}=C_{t}\left(L L_{c}\right)^{n=0,3}$

$Q_{p}=\frac{C_{p} A}{T_{p}}$.

$T=3+\frac{t_{p} A}{8}$
$t_{D}=\frac{t_{p}}{5,5}$

Apabila durasi hujan efektif tr,tidak sama dengan durasi standar $t_{D}$, maka :

$t_{p R}=t_{p}+0,25\left(t_{r}-t_{D}\right)$

$Q_{p R}=Q_{p} \frac{T_{p}}{T_{p R}}$

Dimana:

$t_{p}$ : waktu dari titik berat hujan efektif ke puncak hidrograf satuan

$C_{t}$ : Koefesien yang tergantung pada karesteristik DAS, yang bervariasi antara1,4 smapai 1,7

L : Panjang sungai terhadap titik kontrol yang ditinjau $(\mathrm{km})$

$Q_{p}$ : Debit puncak durasi untuk $t_{D}$ $L_{C}$ :Panjang DAS utama dari titik berat / kontrol hujan bert efekti ke puncak hidrograf

$C_{P}$ : Koefesien yang tergantung pada karesteristik DAS,yang bervariasi antara 0,15 sampai 0,19

$t_{D}$ : Durasi standar dari hujan efektif (jam)

$t_{p R}$ : Waktu dari titik berat durasi hujan efektif $t_{r}$ kepuncak hidrograf satuan (jam)

$t_{r}$ :Durasi Hujan Efektif ( jam )

$Q_{p R}$ : Debit Puncak untuk durasi $t_{r}$

\section{METODE PENELITIAN}

\section{Lokasi Penelitian}

Daerah Aliran Sungai (DAS) Maros secara administratif terletak di wilayah Kabupaten Maros dan Kabupaten Gowa 
di provensi Sulawesi Selatan,tepatnya berada di Kecamatan Marusu, Maros Baru, Turikale, Mandai, Tanrilili, Simbang, dan Bantimurung serta Cenrana dan Tompobulu Kabupaten Maros dan Kecematan Tinggi Moncong Kabupaten Gowa. Dan secara geografis terletak anatara $4^{\circ} 58^{\prime} 40^{\prime \prime} \mathrm{LS}$ dan $119^{\circ}$ $55^{\prime} 38^{\prime \prime}$ BT.

\section{Pengumpulan Data}

Data yang digunakan dalam penelitian adalah data-data skunder yang diperoleh dari Balai Wilayah Sungai Pompengan Provensi Sulawesi Selatan, Data yang dimaksud seperti:

1) Peta Topografi Das Maros Sub Das Maros-Tompubulu

2) Karakteristik Das Maros Sub Das Maros-Tompubulu

a) Luas Das

b) Panjang sungai

c) Kemiringan sungai

3) Data Curah Hujan

Data curah hujan diperoleh dari Balai Wilayah Sungai Pompengan Provinsi Sulawesi Selatan.

4) Data AWLR

Data Automatic Water Level Recorder (AWLR) berupa data tinggi muka air di peroleh dari Balai Wilayah Sungai Pompengan Provensi Sulawesi-Selatan.

\section{MetodeAnalisis Data}

Metode Analisis Data menggunakan Hodrograf Satuan Metode Collins dan Metode Snyder dengan langkah-langkah sebagai berikut:

1) Analisis Hidrograf Satuan Collins

Merujuk pada pembahasan pada bab dua tentang pembahasan Hidrograf Satuan Sintesis, sesuai apa yang tertera pada bab dua, maka ada beberapa komponen penunjang secara umum dalam analisis HS Collins diantaranya:

a) Memilih data hujan jam-jaman otomatis

b) Menganalisa volume limpasan

c) Menganalisa indeks infiltrasi ( $\phi$ indeks)

d) Menganalisa komponen hidrograf dan perhitungan hujan efektif

Analalisis Hidrograf Satuan Sintesis Snyder

a) Mengukur Luas das sungai dalam hal ini Das Maros A (Km2)

b) Mengukur Panjang Alur Karakteristik Das Maros Sub Das MarosTompubulu L(Km)

c) Menentukan jarak titik berat Das dengan titik tinjau (Lc) 


\section{Flow Cart Penelitian}

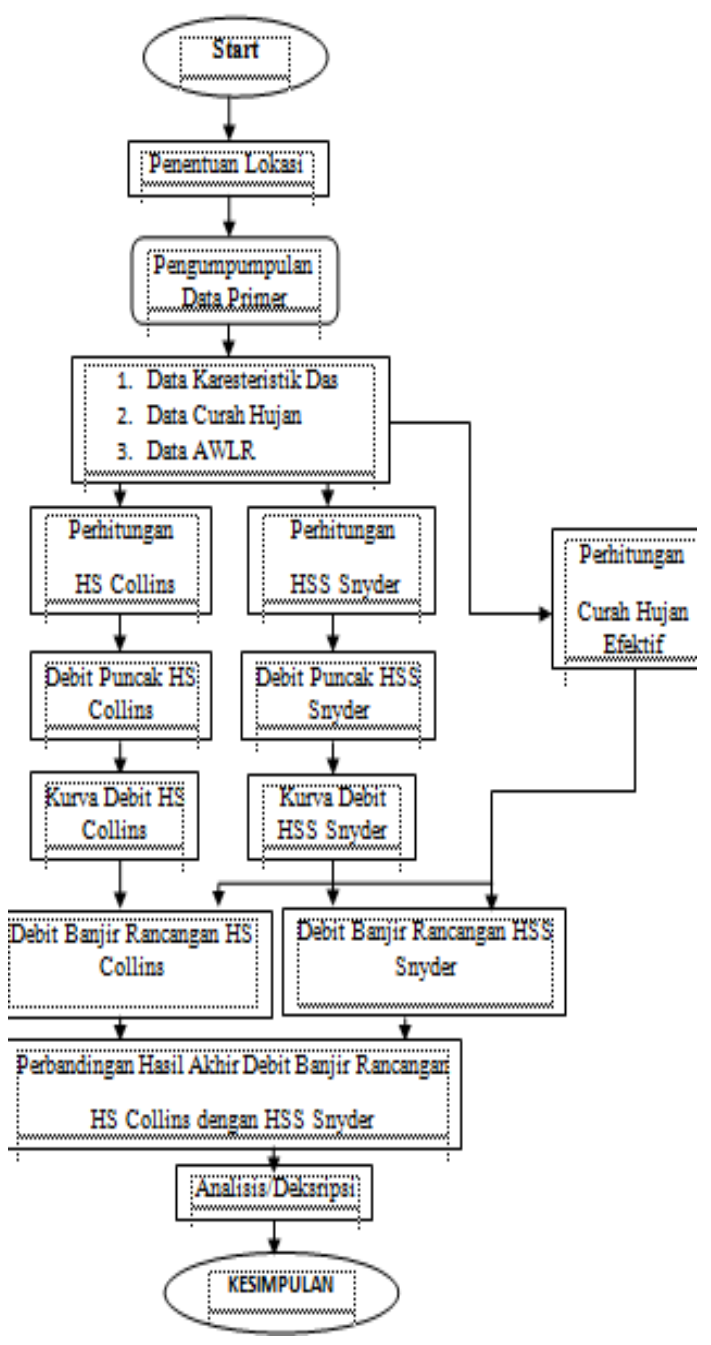

HASIL DAN PEMBAHASAN

\section{Penentuan Lengkung Debit}

Lengkung aliran debit (Discharge Rating Curve), adalah kurva yang menunjukkan hubungan antara tinggi muka air dan debit pada lokasi penampang sungai tertentu. Debit sungai adalah volume air yang melalui penampang basah sungai dalam satuan waktu tertentu, biasanya dinyatakan dalam satuan $\mathrm{m} 3 /$ detik atau 1/detik.

Lengkung aliran dibuat berdasarkan data pengukuran aliran yang dilaksanakan pada muka air dan waktu yang berbedabeda. Kemudian data pengukuranan aliran tersebut digambarkan pada kertas arithmatik atau kertas logaritmik, tergantung pada kondisi lokasi yang bersangkutan. Tinggi muka air digambarkan pada sumbu vertikal sedang debit sumbu horizontal.

Dari data pengukuran debit pada tabel 1 dapat dibuat grafik sebagai berikut. Dari hasil data debit maksimum tahunan dibuat lengkung debit dengan menggunakan grafik linear regresi sehingga muncul persamaan dari grafik tersebut yakni $\mathrm{Q}=(\mathrm{a} \times \mathrm{H})^{b}$

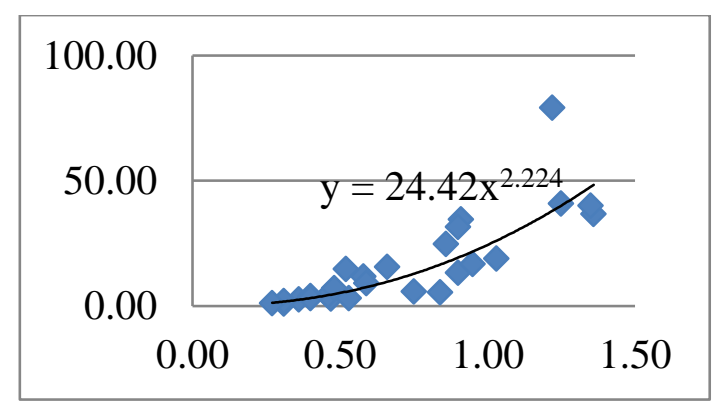

Analisis Hasil Perbandingaan Hs Amatan Dan Hss

Sebagaimana yang dibahas pada bab I tentang rumusan masalah, yang menjadi indikator dalam perbandingan Hidrograf 
Satuan Amatan dan Hidrograf Satuan

Sintesis maka di peroleh analisis perbandingan pada grafik dibawah ini:

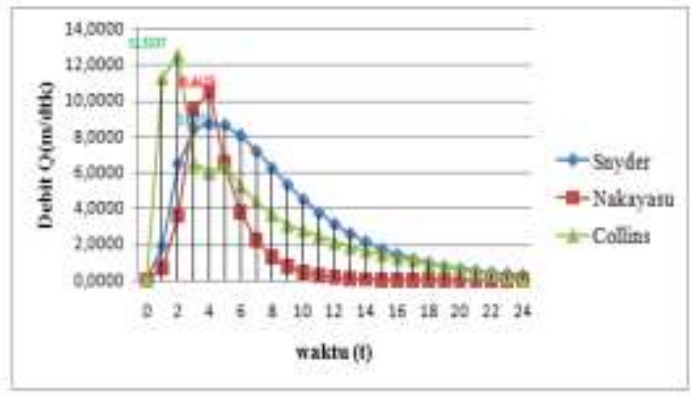

Gambar 3 : Debit Banjir Rancangan HS dan HSS

Dari gambar kurva diatas kita dapat melihat perbandingan hasil perhitungan Debit Puncak Metode Hs Collins, Hss Snyder dan Nakayasu. Di gambar tersebut terlihat perbedaan yang cukup signifikan antara debit puncak $\mathrm{Hs}$ Collins dan Hss Snyder dan Nakayasu. Dari hasil perhitungan debit puncak, didapatkan Qp untuk metode Hs Collins pada jam (tp) $02.00=12,5337 \mathrm{~m}^{3} /$ detik sedangkan untuk metode HSS Nakayasu didapatkan Qp jam (tp) 3,12=10,4625 $\mathrm{m}^{3}$ /detik, untuk Hss Snyder pada jam (tp) 3,68 di peroleh Qp $=.8,653$ $\mathrm{m}^{3} /$ detik. Dari hasil perhitungan tersebut didapatkan selisih Qp antara Hs Collins dan Nakayasu pada $=2,0712 \mathrm{~m}^{3} /$ detik, sedangkan selesih antara Hs Collins dan Hss Snyder 3,8384 m³/detik.

\section{PENUTUP}

\section{Kesimpulan dan Saran}

Kesimpulan

Dari hasil pembahasan dan perhitungan dalam tugas akhir ini, maka kami dapat menarik beberapa kesimpulan terkait Penerapan Metode HS Collins dan HSS Snyder Pada DAS Maros sub DAS Maros-Tompobulu yaitu

1) Kedua metode yang digunakan dalam tugas akhir ini masing-masing memiliki parameter yang berbeda dalam pengaruh terhadap perubahan waktu mencapai puncak dan debit puncak. Pada metode HS Collins parameter Lc menjadi sangat berpengaruh untuk perubahan waktu mencapai puncak. Dan pada metode HS Snyder parameter $\alpha$ dan tg yang menjadi sangat berpengaruh untuk perubahan waktu mencapai puncak.

2) Dengan melihat hasil yang didapatkan dari perhitungan dan pembahasan, maka dapat dianggap bahwa metode HS Collins dan HSS Snyder dapat digunakan dalam menentukan debit banjir rancangan pada DAS Maros sub DAS Tompobulu. 
Tetapi untuk memastikannya diperlukan penelitian lebih lanjut.

\section{Saran}

Sebagai penutup tulisan ini, kami ingin menyampaikan beberapa saran kepada seluruh pihak terkait tugas akhir kami ini yaitu :

\section{Daftar Pustaka}

Harto, S,.1993 Analisis Hidrologi, P.T. Gramedia Pustaka Utama, Jakarta.

Linsley Jr, R,K., M.A., Paulus, J.L.H., (1989), Hidrolgi untuk Insinyur,Edisi ketiga, (diterjemahkan oleh : Yandi Hermawan),Penerbit Erlangga, Jakarta.

Rakhim, Abd, 1998, Analisis Hidrograf Satuan untuk Menghitung DebitBanjir Rancangan (Studi Kasus di DAS Jeneberang, SulawesiSelatan), Thesis, Universitas Brawijaya, Malang.

Seyhan, E., 1977, Dasar - Dasar

Hidrologi, (diterjemahkan oleh

:Subagyo. S), Gajah Mada

University, Yogyakarta.

Sosrodarsono, D., Tekad, K 1983, Hidrologi untuk Pengairan, Pradnya Pramitra, Jakarta.

Trimatdjo, Bambang, (2008), Hidrologi Terapan, Beta Offset, Yogyakarta.

Wilson, E.M., 1993, Hidrologi Teknik, (diterjemahkan oleh : Marjuki. A),Peberbit Erlangga, Jakarta.

Anonymous, Analisis Hidrologi Banjir Rancangan (Design Flood), Mahasiswa Jurusan Teknik Sipil dan Lingkungan Fakultas Teknik UGM,diakses 15 Januari2016) 